Relations industrielles

Industrial Relations

\title{
The Personal Manager
}

\section{T. Roger McLagan}

Volume 2, numéro 9, mai 1947

URI : https://id.erudit.org/iderudit/1023882ar

DOI : https://doi.org/10.7202/1023882ar

Aller au sommaire du numéro

Éditeur(s)

Département des relations industrielles de l’Université Laval

ISSN

0034-379X (imprimé)

1703-8138 (numérique)

Découvrir la revue

Citer cet article

McLagan, T. (1947). The Personal Manager. Relations industrielles / Industrial Relations, 2(9), 6-7. https://doi.org/10.7202/1023882ar

Tous droits réservés @ C Département des relations industrielles de l’Université Laval, 1947
Ce document est protégé par la loi sur le droit d'auteur. L’utilisation des services d'Érudit (y compris la reproduction) est assujettie à sa politique d'utilisation que vous pouvez consulter en ligne.

https://apropos.erudit.org/fr/usagers/politique-dutilisation/ 


\section{THE PERSONAL MANAGER}

\section{FUNCTIONS OF A PERSONNEL MANAGER}

In my opinion, the cardinal principle which should be followed by a Personnel Manager is one of justice. In speaking of justice, it should be rememocred that there are two parties involved, namely, the Employee and the Management. He is a dual personality. When he i.s negotiating with the Nianagement, he should be taking the part of the Employee, and when he is negotiating with the Employees, he should be taking the part of the Management. It may seem to be a pecullar function, but that is what must be kept in mind if a Personnel Manager is to be successful.

The next point to be kept in mind is that a Personnel Manager must be cost minded. Just because he is in charge of personnel does not mean that he has a closed mind to the main functions of the business, which are to employ people and make a profit. He should be just as cost minded as the Superintendents in the Plant. In fact, he should be more so as he is really in a higher Executive post.

The Personnel Manager, in my opinion, is a very important person, and he should be responsible to the Chief Operating Executive. $\mathrm{He}$ is not just an ordinary person who is taking orders from someone else, but he should be a man of great initiative, because he is performing functions for which it is difficult to evolve a set of detailed rules. In my opinion, more and more attention has got to be paid by Business to the functions of the Personnel Department. It is just as important to pay attention to the human relations as it is to the Public Relations.

The Personnel Manager should be considered in charge of internal publicity and propaganda. In a large organization where there are a lot of human beings, it is necessary for someone to carefully arrange the publicity so that the employees are posted on what is going on and so that bad propaganda can be counteracted.

\section{OFFICE RECORDS}

As regards the operating functions of a Personnel Manager, it is important that very accurate office records be kept of employees. You cannot operate the business without cost records and, therefore, you cannot operate an Employment Department without a proper set of office records. I cannot stress this matter too much, as it is one which has been sadly neglected over the years.

There should be a well defined Standard Practice regarding the records to be kept. It should follow conventional bookkeeping records. The guiding principle should be that from the time that a man is hired to the time that the man is discharged or leaves the employ of the Company, a complete set of records should be kept as to what has happened to him. There should be an office journal showing those who are hired and discharged and transferred.

Upon entry into the Plant, a history sheet should be made out, and it should be filed in a folder in the Office. There should be forms made out for the hiring, firing, change of rate, transfer, etc., of the man, and all this history should appear on a convenient form in the Office. If the man should leave, his records should be gathered up and placed in a dead file in alphabetical order. In this way, if this man should return, the Employment Utticer has the full record of his history in the Plant and, if he is a suitable employee for reemployment, his record is simply taken out of the dead file and put in the live file.

'I hese Employment Office forms should not be voluminous, but they should be very efficient and they should be carefully made out so that one form may do for a number of different functions. The Personnel Manager should see that the Employment Office records are meticulously kept.

\section{HIRING AND DISCHARGING OF EMPLOYEES}

The Personnel Manager should be in complete charge of the hiring and discharging of all employees. When Superintendents require new men, they send a requisition for same to the Personnel Department in the same way as they send a requisition for materials to the Purchasing Department. This does not mean that the Personnel Manager can force Superintendents to take any kind of a man. It is the function of a Personnel Manager to seek out good men and get them into the Plant in the same way as the Purchasing Department seeks out good materials to be used in the Plant. The main point, however, is that the indiscriminate hiring of employees by Foremen should not be allowed. I have found, in many cases, that Foreman will tend to get their Department filled with relatives or friends, etc., and we are hiring men for their use as efficient operators.

Where men have to be discharged, the Superintendent of Foreman concerned will notify the Personnel Manager that he no longer needs such an employee. It is up to the Personnel Manager, in the first place, to see that no injustice is being done in discharging this particular person. We have laws in this country which prescribe what we are to do, and the Personnel Manager is required to see that those laws are followed.

All raise increases should be in the form of recommendations for a raise to the Personnel Department, who, in turn, no doubt, will have it confirmed, if he concurs, by the Chiet Executive Officer. In my opinion, recommendations for increasing individuals' wages should be very carefully scrutinized to see that, first, such an increase is justified, and secondly, that it is not out of line with the policy of the Company or in relation to other employees performing the same function. I feel strongly that Foremen do not have the final say in what the employees' wages are going to be.

On this policy of hiring and firing employees, the Personnel Manager, when asked for new employees, should try and fill the requisition from existing staff, rather than hire indiscriminately. This founction is performed by a Storekeeper, who will try and fill his material requisitions from stock rather than buy new goods. In many cases, a Personnel Manager, if he tries, can sometimes transfer an employee from one Department to another-and fill the vacancy without increasing the payroll.

\section{RELATIONS WITH TRADE UNIONS}

All relations with Trade Unions should be through the Personnel Manager. He should be a man that has the knowledge of the existing Labour rules and regulations at his finger tips. He should see that a proper set of ruies 
of work are made up, which may or may not be part of a Trade Union Agreement. In any event, the Employment Supervisor should carry out all the relations with the Union Leaders, and he should make it his business to know them personally and to convince them of his honesty and desire to deal with them and live up to their agreements.

The Personnel Manager should settle all disputes, and the more disputes he settles the less troubles with labour there will be. $\mathrm{He}$ should be a regular listening post of the Company, and should try and eliminate disputes or aggravations before they become serious.

\section{MEDICAL SERVICES}

The hiring of new employees brings us to the question of a medical service in the Plant, and an efficient Personnel Supervisor should be the Officer of the Company in charge of the Medical Services, if there be one. It is important that employees be medically examined before being taken on, so that the Company does not employ men with contagious diseases or men with disabili$t$ es which are liable to involve them or their fellows in an accident in the Plant. It is important that the Personnel Manager observe these matters very strictly and, if there be a Pension Service in the Company, he should pay particular attention to the age and physical ability of the employee.

\section{SAFETY SERVICES}

This brings us also to the Safety Service. In my epinion, the Safety Supervisor of the Plant shotld report to the Personnel Manager. The Personnel Manager should draw up very carefully the rules and regulations of the Safety Service, and he should see that meetings of the Safety Committee are properly carried out, attending all the meetings and carefully reading all the minutes of the meetings. He should draw up a careful set of safety regulations and, here again, internal propaganda is very important. He should be careful to see that the cause of safety is promoted in the Plant and, again, the matter of safety records efficiently kept shouid be carried out.

\section{APPRENTICE SYSTEM}

In order that a supply of well trained young meis are constantly passing through the organization, the Personnal Manager should have charge of the Apprentice system. He should see that the correct number of apprentices are constantly moving up through the various trades. He should lay out for them the course of instruction they should have and, more important, he should see that these boys are moved from function to function so that they are getting properly trained. In this connection, also, I might mention the policy of summer students into the Plant in the summer month several years before they graduate so that he can obtain first class material for the Plant.

\section{WELFARE AND CANTEENS}

He should be in charge of all employees' welfare activities, such as Mutual Benefit Associations, Sick
Benefit, Life Insurance schemes, etc., and canteens. Where possible, all these activities should be co-ordinated, and he should encourage the study of the welfare of all the employees by Committees of the employees. It means a great deal to an organization to have someone watching over the welfare of its people. Where a large body of men is concerned, there is always someone getting into trouble or someone needing help, and the Personnel Manager should see that this help is forthcoming. It is best done by the organization of all the workers into a $\mathrm{CO}_{\text {- }}$ operative welfare scheme. The supervision of the canteens is most important because they are being used by the men and, where possible, the profits of these canteens should go to the Welfare Fund.

I have mentioned before the matter of knowledge of cost of production. Where possible, the Personnel Manager should be a man who has come up through the organization and has a knowledge of the various productive functions. Whether he has come up through the organization or not, it is most essential he should study the various jobs or trades in those Departments. $\mathrm{He}$ must have a knowledge of job evaluation, and he should be able to talk intelligently about the various jobs. In this connection, I mention the question of time study. I find in various educational institutions, that emphasis on this has been completely neglected. It is a most important matter in industry today, and it is one which a Personnel Manager should have some knowledge of. It may come up in the policy of wage rates and in the relations with Trade Unions.

I finally bring up the question to you of daily contacts in the Plant. The Personnel Manager should not be one who sits in an office chair. He should be constantly out in the Plant keeping in touch with the operations and talking to the various men, and conferring with the Foremen about their needs. By doing so, he will hear of the various little complaints of the men and, in my opinion, many of these complaints are either justified or based on misinformation. The Personnel Manager must, of necessity, take the time to run these down and keep down complaints. If an organization lets a Labour leader come down and make that organization correct some grievances which the organization should have done itself, then it means that the Personnel Manager has fallen down on the job.

\section{T. Roger McLagan}

\section{NOS COLLABORATEURS}

Dion. Gérard, L.Th., L.Ph.. M.Sc.Soc., secrétaire du Département des relations industrielles de l'Université Laval.

Forget, Marcel, secrétaire adjoint de la Fédération des comités paritaires de la province de Québec.

McLagan, T. Roger. Member Canadian Engineering Institute, de la firme Dufresne, McLagan and Associates, Reg'd., et gérant général de Canadian Vickers Limited, Montréal.

Quimper, Donat, LL.L., directeur adjoint du Service de conciliation et d'arbitrage du ministère du Travail. 